\title{
Efektifitas Model Pembelajaran Inkuiri Terbimbing untuk Meningkatkan Kemampuan Bepikir Kritis Mahasiswa
}

\author{
Isnanik Juni Fitriyah ${ }^{1}$, Yessi Affriyenni ${ }^{2}$, Erti Hamimi ${ }^{3}$ \\ Program Studi Pendidikan IPA, Fakultas Matematika dan IPA, Universitas Negeri Malang ${ }^{1,2,3}$ \\ Isnanik.fitriyah.fmipa@um.ac.id ${ }^{1}$, yessi.fmipa@um.ac.id ${ }^{2}$, erti.hamimi.fmipa@um.ac.id ${ }^{3}$
}

\begin{abstract}
Abstrak
Penelitian ini memiliki tujuan untuk mengetahui keefektifan model pembelajaran inkuiri terbimbing dalam meningkatkan keterampilan berpikir kritis pada mahasiswa. Dengan menggunakan jenis penelitian studi literasi, pengumpulan artikel yang dilakukan dengan bantuan mesin pencari Harzing's Publish Or Perish dengan kriteria yang digunakan yaitu artikel diterbitkan pada tahuan 2010-2020 namun diutamakan pada artikel yang diterbitkan pada 20152020. Hasil studi literasi yang telah dilakukan diperoleh bahwa keterampilan berpikir kritis yang dimiliki mahasiswa masih rendah sehingga diperlukan pengembangan keterampilan berpikir kritis. Padahal keterampilan berpikir kritis seharusnya dimiliki oleh masing-masing mahasiwa karena menjadi salah satu standart kelulusan perguruan tinggi. Salah satu cara untuk meningkatkan keterampilan berpikir kritis yaitu dengan pemilihan model pembelajaran yang tepat. Model pembelajaran inkuiri terbimbing menjadi salah satu model pembelajaran yang efektif dalam meningkatkan keterampilan berpikir kritis termasuk dalam meningkat keterampilan berpikir kritis pada mahasiswa. Hal ini dikarenakan sesuai dengan metode pengembangan keterampilan berpikir kritis mahasiswa yaitu dengan merumuskan pertanyaan atau permasalahan.

Kata Kunci: Berpikir Kritis; Inkuiri Terbimbing; Model Pembelajaran

\section{Abstract}

This research has a purpose to determine the effectiveness of guided inquiry learning model in improving students's critical thinking skills. By using the type of literacy study research, the collection of articles is carried out with the help of the Harzing's Publish Or Perish search engine with the criteria used, namely the article published on the ignorance 2010-2020 but preferably on the article published in 2015-2020. The results of the literacy study that have been conducted show that the critical thinking skills possessed by students are still low, so that it requires the development of critical thinking skills. Though critical thinking skills should be possessed by each student because it is one of the standards for college graduation. One way to improve the critical thinking skills is by selecting the rght learning model. The guided inquiry is one of the effective learning models in improving critical thinking skills, including in increasing critical thinking skills in students. This is because it is in accordance with the method of developing students' critical thinking skills, namely by formulating questions or problems.

Keywords: Critical Thinking; Guided Inquiry; Learning Models
\end{abstract}

$$
\text { Diterima (11 Juli 2021) Disetujui (16 Juli 2021) Dipublikasikan (2 September 2021) }
$$

\section{PENDAHULUAN}

Dalam menghadapi era globalisasi dan perkembangan ilmu pengetahuan teknologi yang semakin pesat saat ini diperlukan sumber daya manusia yang memiliki kualitas yang baik. Pendidikan menjadi salah satu upaya menumbuhkan kemampuan, bakat dan potensi dalam diri seseorang. Dengan pendidikan, siswa sebagai calon generasi penerus bangsa akan lebih sadar dan responsif terhadap arah perubahan dan perkembangan ilmu pengetahuan dan teknologi (Nurkholis, 2013).

Pendidikan mampu meningkatkan keterampilan sumber daya manusia dalam menghadapi tantangan abad ke-21. Keterampilan dalam abad ke-21 meliputi kecakapan hidup dan kecakapan 
lahir, baik dalam hal teknologi, media serta pemikiran yang lebih kritis dan inovatif (Rambe dkk., 2020). Dari beberapa keterampilan pada abad ke-21 tersebut, keterampilan berpikir kritis menjadi salah satu keterampilan yang harus dimiliki generasi muda saat ini.

Keterampilan berpikir kritis menjadi bekal intektual yang harus dimiliki oleh masing-masing pribadi. Berdasarkan penelitian yang dilakukan oleh Darek Bok dalam Roviati \& Widodo (2019), keterampilan berpikir kritis merupakan salah satu hal yang harus dimiliki oleh seseorang dalam tingkat pendidikan sarjana. Hal ini juga tercantum dalam Permendikbud No 49 tahun 2014 tentang Standar Nasional Pendidikan Tinggi Pasal 6 bahwa lulusan program sarjana harus memiliki keterampilan umum diantaranya dapat bersikap dan berpikir secara logis, kritis, sistematis, serta memiliki inovasi dalam lingkup pengembangan ilmu pengetahuan dan teknologi dengan memperhatikan dan menerapkannya pada nilai humaniora yang disesuaikan dengan bidang keahlian. Namun, berdasarkan survei yang dilaksanakan oleh Idris (2018) dan Anugraheni (2020), mengungkap bahwa keterampilan berpikir kritis yang dimiliki mahasiswa masih tergolong rendah.

Keterampilan berpikir kritis menjadi hal yang sangat esensial dalam proses menuju manusia dewasa. Keterampilan berpikir kritis berdasarkan Putra \& Sudarti (2015) adalah keterampilan berpikir yang dapat membentuk seseorang mampu mengevaluasi ataupun menyelidiki dengan dasar berupa fakta, bukti, asumsi serta logika yang membedakannya dengan pemikiran dari orang lain.

Cara dalam menanggapi dan menyelesaikan suatu permasalahan menjadi karakter khusus seseorang yang memiliki keterampilan berpikir kritis. Hal ini dikarenakan seseorang yang memiliki keterampilan berpikir kritis memiliki kemampuan merumuskan solusi terbaik sesuai dengan permasalahannya. Indikator keterampilan berpikir kritis dapat dikategorikan menjadi tiga yaitu mampu: 1) merumuskan pokok masalah, 2) mengungkap fakta yang diperlukan untuk menyelesaikan masalah, dan 3) mengungkapkan argumen yang masuk akal dan akurat (Rusmansyah dkk., 2019).

Keterampilan berpikir kritis penting ditingkatkan dan dikembangkan dalam melakukan penyelesaian masalah kehidupan sehari-hari. Terlebih lagi permasalahan di era globalisasi saat ini menjadi semakin kompleks sehingga diperlukan kemampuan individu dalam menyelesaikan masalah secara tepat. Tidak hanya itu, keterampilan berpikir kritis juga diperlukan dalam dunia pendidikan untuk melahirkan lulusan yang mampu bersaing di pasar kerja yang memiliki tantangan yang semakin berat kedepannya (Juhji \& Suardi, 2018).

Salah satu cara untuk meningkatkan keterampilan berpikir kritis di dunia pendidikan adalah dengan menerapkan model pembelajaran inkuiri terbimbing. Hal ini sesuai dengan penelitian yang dilakukan oleh Putri dkk. (2019) bahwa inkuiri terbimbing yang merupakan salah satu model pembelajaran saintifik menekankan pada proses siswa berpikir kritis dan analitis untuk menemukan suatu jawaban dari satu permasalahan. Dalam pelaksanaannya, siswa akan mampu mencari dan menyelidiki sesuatu secara sistematis, logis, analitis dan kritis sehingga sampai ke perumusan temuannya masing-masing.

Inkuiri terbimbing mengenalkan cara dalam meningkatkan pengetahuan konsep, kemampuan serta sikap melalui pertanyaan yang mengarah ke penyelidikan. Inkuiri terbimbing merupakan bagian dari strategi pembelajaran induktif. Inkuiri terbimbing ini termasuk ke dalam pembelajaran berbasis masalah dengan metode penyelidikan (Nasution, 2018).

Penelitian yang dilakukan oleh Azizah dkk. (2016) mengungkap bahwa keterampilan berpikir kritis siswa mengalami peningkatan setelah mengikuti pembelajaran dengan menggunakan model inkuiri terbimbing. Penelitian lain yang dilakukan oleh Harahap dkk. (2020) juga memperoleh hasil yang serupa yaitu dengan menerapkan model inkuiri terbimbing, keterampilan berpikir kritis siswa lebih meningkat dibandingkan dengan model pembelajaran proyek dan tradisional.

Pembelajaran model inkuiri terbimbing dapat diterapkan dengan menggunakan beberapa cara diantaranya merumuskan pertanyaan, diskusi, demonstrasi ataupun kegiatan di laboratorium. Terdapat 6 langkah pembelajaran inkuiri terbimbing yaitu 1) penentuan pertanyaan atau 
permasalahan, 2) perumusan hipotesis, 3) perancangan percobaan, 4) percobaan untuk memperoleh informasi, 5) pegumpulan dan penganalisisan data, dan 6) perumusan kesimpulan (Pitorini dkk., 2020).

Dalam penelitian ini, peneliti bertujuan mengungkap keefektifan penerapan model inkuiri terbimbing dalam meningkatkan keterampilan berpikir kritis pada mahasiswa sebagai salah salah satu keterampilan yang harus dimiliki di era globalisasi.

\section{METODE}

Penelitian ini menggunakan metode studi literasi, yakni dengan cara mengumpulkan data literasi baik nasional maupun internasional. Tahapan yang dilakukan adalah:

\section{Pencarian Topik}

Tahap pencarian topik dilakukan dengan menggunakan kata kunci inkuiri terbimbing (guided inquiry) dalam meningkatkan keterampilan berpikir kritis pada mahasiswa.

\section{Studi Literatur}

Pada tahap ini dilakukan penelusuran artikel dengan menggunakan kata kunci inkuiri terbimbing dan keterampilan berpikir kritis dengan menggunakan Google Scholar dengan berbantuan program Harzing's Publish or Perish (HPOP). Studi literatur pencarian sumber referensi diutamakan pada jurnal terindeks sinta dan scopus. Berdasarkan kata kunci tersebut diperoleh artikel sebanyak 1.949 dari tahun 2010 hingga tahun 2020. Artikel yang telah diperoleh tersebut kemudian dilakukan identifikasi untuk disesuaikan dengan artikel yang dibuat.

\section{Pembahasan dan Analisis Data}

Pada tahap ini dilakukan analisis terhadap keterhubungan antara dua kata kunci, yakni inkuiri terbimbing dengan kemampuan berpikir kritis mahasiswa. Dengan melihat keterhubungan tersebut akan diketahui keefektifan penggunaan model inkuiri terbimbing dalam meningkatkan keterampilan berpikir kritis pada mahasiswa

\section{HASIL DAN PEMBAHASAN}

\section{Hasil}

Berdasarkan studi literasi yang telah dilakukan pada penelitian-penelitian dalam artikel ilmiah, didapatkan bahwasanya:

1. Keterampilan berpikir kritis mahasiswa masih kurang (Farcis, 2019; Kurniawan \& Aprodita, 2020; Nuraini, 2017; Oktariani dkk., 2020).

2. Proses perkuliahan yang dilakukan oleh mahasiswa belum dapat mengasah keterampilan berpikir kritis (Farcis, 2019; Hadi \& Junaidi, 2020; Nuraini, 2017; Oktariani dkk., 2020; Suparya, 2020).

3. Keterampilan berpikir kritis perlu dimiliki sebagai bekal menghadapi perkembangan dunia abad 21 (Oktariani dkk., 2020)

4. Keterampilan berpikir kritis perlu dimiliki mahasiswa sebagai bekal untuk menghadapi dunia pekerjaan (Nuraini, 2017; Oktariani dkk., 2020)

5. Cara yang dapat dilakukan untuk meningkatkan keterampilan berpikir kritis mahasiswa adalah dengan merancang proses perkuliahan yang mampu merangsang mahasiswa untuk berpikir kritis seperti penerapan model pembelajaran tertentu (Putri dkk., 2019)

6. Model pembelajaran guided inkuiri mampu meningkatkan keterampilan berpikir kritis mahasiswa (Azizah dkk., 2016; Rositawati, 2019; Sitindaon dkk., 2017; Supriyatno dkk., 2020).

\section{Pembahasan}

\section{A. Rendahnya Keterampilan Berpikir Kritis Mahasiswa}


Berdasarkan penelusuran yang dilakukan pada artikel, diperoleh jika rendahnya keterampilan berpikir kritis yang dialami oleh mahasiswa disebabkan salah satunya penggunaan metode pembelajaran yang kurang efektif (Iman dkk., 2017). Di lapangan, masih ditemui pembelajaran yang menggunakan metode ceramah. Dengan metode ini, pendidik berperan penuh dalam memberikan informasi pembelajaran. Metode ini menyebabkan mahasiswa memiliki keterampilan mengonstruksi suatu konsep yang rendah. Padahal, di era globalisasi ini seharusnya pembelajaran dilakukan secara bermakna dimana mahasiswa mampu mengonstruksi konsep yang dibangun dari dalam dirinya masing-masing.

Mahasiswa seringkali tidak dituntut untuk melakukan pengembangan keterampilan berpikir kritis yang dimiliki. Hal ini menyebabkan mahasiswa hanya memiliki kemampuan teori yang baik namun minim dalam penerapannya. Akibat dari hal tersebut, keterampilan berpikir kritis pada mahasiswa tidak terasah dan sulit untuk ditingkatkan.

Keterampilan berpikir kritis pada mahasiswa tidak dapat langsung muncul secara alamiah. Keterampilan berpikir kritis dapat muncul dikarenakan stimulus dari lingkungan. Oleh karena itu, keterampilan berpikir kritis pada dasarnya dapat dilatih kepada mahasiswa dengan cara menerapkan pembelajaran dengan strategi yang sesuai.

\section{B. Pentingnya Mahasiswa Memiliki Keterampilan Berpikir Kritis}

Paradigma perubahan pendidikan di abad ke-21 ditunjukkan dengan adanya tuntutan perubahan pola pikir pada manusia. Dengan kerangka yang telah dikembangkan oleh Partnership for $21^{\text {st }}$ Century Learning yang menyebutkan bahwa di abad 21, peserta didik dituntut memliki keterampilan berpikir kritis. Tuntutan ini tentunya menyebabkan perubahan pada sistem pendidikan nasional. Pembelajaran konvensional yang masih berupa penghafalan teori diubah menjadi pembelajaran yang lebih bermakna. Walaupun hingga saat ini tidak bisa dipungkiri bahwa di lapangan masih terlaksana pembelajaran yang pendidik memegang dominasi penuh. Dominasi penuh pendidik ini menyebabkan peran peserta didik pada pembelajaran hanya sebuah objek semata (Majir, 2020).

Oleh karena itu, dalam menghadapi abad ke-21, Kemendikbud RI telah menyarankan pembelajaran yang menekankan pada proses ilmiah berupa perumusan masalah, berpikir analisis dan kolaborasi dalam mencari suatu solusi. Berdasarkan hal tersebut, diharapkan pendidik, baik guru maupun dosen mampu merancang pembelajaran yang dapat meningkatkan proses ilmiah khususnya keterampilan berpikir kritis peserta didik (Redhana, 2019).

Keterampilan berpikir kritis penting dimiliki terutama pada peserta didik tingkat perguruan tinggi. Hal ini dikarenakan persiapan peserta didik perguruan tingg dalam rangka memasuki dunia kerja. Keterampilan berpikir kritis yang dimiliki oleh setiap mahasiswa akan memengaruhi kesuksesan dan juga keprofesionalitas (Redhana, 2019).

Dengan menghasilkan lulusan mahasiswa dengan keterampilan berpikir kritis yang tinggi dapat digunakan sebagai bekal menghadapi abad ke-21. Hal ini tentunya akan meningkatkan pula kualitas sumber daya manusia yang menjadi cerminan dari kemajuan suatu bangsa. Terlebih, hasil survei HDI (Human Development Indeks) menunjukkan bahwa kualitas sumber daya manusia Indonesia berada pada peringkat 110 dari 183 negara dengan indeksnya yaitu 0,689 (Yolanda, 2017). Peringkat tersebut menunjukkan jika kualitas sumber daya manusia di Indonesia masih rendah. Hasil tersebut juga dapat mengindikasikan bahwa pembelajaran yang dapat meningkatkan kemampuan berpikir kritis masih belum terealisasi dengan baik.

\section{Peningkatan Keterampilan Berpikir Kritis dengan Model Inkuiri Terbimbing}

Salah satu upaya yang dapat dilakukan untuk meningkatkan keterampilan berpikir kritis pada mahasiswa yaitu dengan menerapkan proses perkuliahan dengan model pembelajaran inkuiri terbimbing. Dalam proses pembelajarannya, mahasiswa akan didorong untuk melakukan pengonstruksian pada pengetahuan melalui kegiatan penelitian dan penyelidikan. 
Penelitian yang dilakukan oleh Maknun (2020) mengungkap bahwa peserta didik yang mengikuti proses pembelajaran dengan penerapan model inkuiri terbimbing menunjukkan tingkat keterampilan berpikir kritis lebih tinggi jika dibandingkan dengan siswa yang melaksanakan pembelajaran secara sederhana. Hasil serupa juga diperoleh pada penelitian yang dilakukan oleh Supriyatno dkk. (2020) di mana terdapat perbedaan antara peserta didik yang diterapkan pembelajaran dengan menggunakan model inkuiri terbimbing dengan peserta didik yang menggunakan pembelajaran konvensional, di mana terdapat peningkatan keterampilan berpikir kritis sebesar 70\% pada peserta yang diberi pembelajaran dengan menggunakan model inkuiri terbimbing.

Keterampilan berpikir kritis mahasiwa dapat ditingkatkan saat proses perkuliahan ketika mahasiswa menerima instruksi yang secara khusus dirancang dengan tujuan meningkatkan keterampilan berpikir kritis (Idris, 2018). Dengan menggunakan metode diskusi yang terarah, keterampilan berpikir kritis mahasiswa juga bisa dilatih dan dikembangkan (Kustyorini \& Mashuri, 2019). Metode lain yang dapat diterapkan dalam rangka meningkatkan keterampilan berpikir kritis pada mahasiswa adalah dengan memberikan pertanyaan mendasar. Hal ini didasarkan pada konsep bahwa seseorang dengan keterampilan berpikir kritis memiliki rasa ingin tahu yang tinggi. Pertanyaan yang dimunculkan dalam pembelajaran juga bukan sekedar pertanyaan faktual yang menyebabkan mahasiswa hanya mengingat fakta. Namun, pertanyaan yang mampu memancing pemikiran siswa dapat berkembang. Dengan pertanyaan tersebut secara tidak langsung akan memicu pemikiran kritis pada mahasiswa.

Dengan kegiatan pengajuan permasalahan, penyajian hipotesis, percobaan dan penganalisisan data dapat meningkatkan keterampilan berpikir kritis peserta didik. Pemecahan masalah yang diberikan juga dikaitkan kepada permasalahan yang sering terjadi di kehidupan sehari-hari peserta didik. Permasalahan nyata ini mampu memicu peserta didik untuk berpikir kritis (Rambe dkk., 2020).

Pada dasarnya, yang membedakan model inkuiri terbimbing dengan model yang lain yaitu pembelajaran dengan pendekatan konstruktivis dengan cara penemuan penelitian. Pembelajaran kontsruktivis ini membuat peserta didik melakukan pencarian sehingga menemukan konsep sendiri. Pembelajaran dengan model inkuiri terbimbing juga akan memberikan pengalaman secara langsung kepada peserta didik dalam mengungkap fakta, sehingga peserta didik tidak hanya belajar dalam memperoleh pengetahuan konsep, namun juga mengembangkan keterampilan proses sains sekaligus keterampilan berpikir kritis di dalamnya (Sumiyarti dkk., 2019).

Keterampilan berpikir kritis sendiri termasuk proses mental dalam seseorang. Individu memerlukan keterampilan dalam membuat, menerapkan, menganalisis, menyintesis dan mengevaluasi informasi yang digunakan dalam mencapai kesimpulan (Changwong dkk., 2018). Proses mental lainnya dalam keterampilan berpikir kritis yaitu proses pemecahan masalah, yakni pengambilan keputusan dengan cara yang terorganisir. Sehingga, upaya dalam meningkatkan keterampilan berpikir kritis juga akan meningkatkan keterampilan pemecahan masalah (Siswanto \& Ratiningsih, 2020).

Langkah berpikir kritis sendiri terdiri dari tiga langkah: 1) pengenalan terhadap permasalahan, 2) penilaian informasi yang relevan, dan 3) pemecahan masalah atau penarikan kesimpulan (Rositawati, 2019). Jika dihubungkan dengan model inkuiri terbimbing, model inkuiri terbimbing merupakan model pembelajaran yang memuat proses dalam perolehan informasi dengan cara pengamatan, penyelidikan atau percobaan untuk menemukan suatu jawaban (Rositawati, 2019). Selain itu, model pembelajaran inkuri terbimbing juga membuat peserta didik mampu menggali pemahaman secara lebih menyeluruh dari proses penyelidikan. Dengan kegiatan penyelidikan yang dimulai dari pengumpulan data, penganalisisan dan penarikan kesimpulan, dapat dikatakan bahwa model pembelajaran inkuiri terbimbing cocok digunakan dalam meningkatkan berpikir kritis mahasiswa (Nisa dkk., 2018). Hal ini dikarenakan sesuai dengan karakteristik dalam proses pengembangan pemikiran kritis pada mahasiswa. Dimana salah satu cara dalam meningkatkan 
keterampilan berpikir kritis yaitu dengan menggunakan proses pemberian pertanyaan atau permasalahan yang mendasar (Irwanto dkk., 2018).

Berdasarkan uraian dari berbagai sumber yang telah disampaikan di atas, disimpulkan bahwa adanya permasalahan kurangnya keterampilan berpikir kritis pada mahasiswa. Di mana sebenarnya keterampilan berpikir kritis ini dibutuhkan untuk menghadapi kehidupan di masyarakat khususnya saat di dunia kerja. Cara yang bisa dilakukan di perkuliahan untuk meningkatkan keterampilan berpikir kritis adalah dengan menerapkan pembelajaran menggunakan model inkuiri terbimbing. Seluruh rangkaian kegiatan dalam inkuiri terbimbing mampu merangsang mahasiswa untuk berpikir kritis.

\section{KESIMPULAN DAN SARAN}

Keterampilan berpikir kritis merupakan salah satu keterampilan yang penting dimiliki serta telah menjadi salah satu tujuan peningkatakan dalam pembelajaran di abad ke-21. Perlu dilakukan pengembangan keterampilan berpikir kritis pada peserta didik terutama pada tingkat perguruan tinggi yang diketahui masih tergolong rendah. salah satu upaya dalam meningkatkan keterampilan berpikir kritis pada mahasiswa dengan pemilihan model pembelajaran dalam perkuliahan yang sesuai. Model pembelajaran inkuiri terbimbing efektif untuk meningkatkan keterampilan berpikir kritis mahasiswa. hal ini didasarkan pada proses kegiatan pembelajaran yang difokuskan pada penyelidikan sehingga mampu menjawab pertanyaan ataupun menyelesaikan masalah yang diberikan.

\section{DAFTAR PUSTAKA}

Anugraheni, I. (2020). Analisis Kesulitan Mahasiswa dalam Menumbuhkan Berpikir Kritis Melalui Pemecahan Masalah. Jurnal Cendekia: Jurnal Pendidikan Matematika, 4(1), 261-267. https://doi.org/10.31004/cendekia.v4i1.197

Azizah, H. N., Jayadinata, A. K., \& Gusrayani, D. (2016). Pengaruh Model Pembelajaran Inkuiri Terbimbing Terhadap Kemampuan Berpikir Kritis Siswa Pada Materi Energi Bunyi. Jurnal Pena Ilmiah, 1(1), 51-60. https://doi.org/10.23819/pi.v1i1.2931

Changwong, K., Changwong, A., \& Sisan, B. (2018). Critical Thinking Skill Development: Analysis of a New Learning Management Model for Thai High Schools. Journal of International Studied, $11(2)$.

Farcis, F. (2019). Profil Keterampilan Berpikir Kritis Mahasiswa Pendidikan Fisika Universitas Palangka Raya dalam Proses Analisis Artikel Ilmiah. Jurnal Jejaring Matematika Dan Sains, 1(1), 52-58. https://doi.org/10.36873/jjms.v1i1.137

Hadi, M. J., \& Junaidi, M. (2020). Prinsip dan Langkah-langkah Penerapan Focus Group Discussion untuk Meningkatkan Keterampilan Berbicara dan Berpikir Kritis Mahasiswa. Jurnalistrendi: Jurnal Linguistik, Sastra Dan Pendidikan, 5(2), 126-134. http://ejournal.unwmataram.ac.id/trendi/article/view/426/219

Harahap, H. S., Turnip, J., \& Sembiring, A. K. (2020). Pengaruh Metode Inkuiri Terbimbing dan Proyek Terhadap Kemapuan Berpikir Kritis Biologi Siswa di SMP Swasta HKBP Simantin Pane. Bio-Lectura: Jurnal Pendidikan Biologi, 7(1), 23-35.

Idris, T. (2018). Profil Berpikir Kritis Mahasiswa Program Studi Pendidikan Biologi Se-kota Pekanbaru. Bioedusiana, 3(2), 1-7. https://doi.org/10.34289/277898

Iman, R., Khaldun, I., \& Nasrullah. (2017). Meningkatkan Kemampuan Berpikir Kritis Siswa Dengan Model Inkuiri Terbimbing Pada Materi Pesawat Sederhana. Jurnal Pendidikan Sains Indonesia (Indonesian Journal of Science Education), 5(1), 52-58.

Irwanto, Saputro, A. D., Rohaeti, E., \& Prodjosantoso, A. K. (2018). Promoting critical thinking and Problem Solving Skills of Preservice Elementary Teachers through Process-Oriented Guided- 
Inquiry Learning (POGIL). International Journal of Instruction, 11(4), 777-794. https://doi.org/10.12973/iji.2018.11449a

Juhji, \& Suardi, A. (2018). Profesi Guru dalam Mengembangkan Kemampuan Berpikir Kritis Peserta Didik di era Globalisasi. Jurnal Genealogi PAI, 5(1), 16-24.

Kurniawan, R. M., \& Aprodita, F. (2020). Analisis Keterampilan Berpikir kritis Mahasiswa pada Materi Kinematika. Jurnal Kependidikan Betara, 1(2), 63-73. https://ejournal.sdn195pinangmerah.com/index.php/jkb/article/view/23

Kustyorini, Y., \& Mashuri, M. T. (2019). Penerapan Pembelajaran Diskusi Analogi untuk Meningkatkan Keterampilan Berpikir Kritis Siswa. Seminar Nasional Pakar Ke 2, 2-6.

Majir, A. (2020). Paradigma Baru Manajemen Pendidikan Abad 21. Deepublish.

Maknun, J. (2020). Implementation of Guided Inquiry Learning Model to Improve Understanding Physics Concepts and Critical Thinking Skill of Vocational High School Students. International Education Studies, 13(6), 117. https://doi.org/10.5539/ies.v13n6p117

Nasution, S. W. R. (2018). Penerapan Model Inkuiri Terbimbing (Guided Inquiry) dalam Meningkatkan Kemampuan Berpikir Kritis pada Pembelajaran Fisika. Jurnal Education and Development, 3(1), 1-5.

Nisa, E. K., Koestiari, T., Habibbulloh, M., \& Jatmiko, B. (2018). Effectiveness of guided inquiry learning model to improve students' critical thinking skills at senior high school. Journal of Physics: Conference Series, 997(1). https://doi.org/10.1088/1742-6596/997/1/012049

Nuraini, N. (2017). Profil Keterampilan Berpikir Kritis Mahasiswa Calon Guru Biologi sebagai Upaya Mempersiapkan Generasi Abad 21. Jurnal Pendidikan Biologi, 1(2), 89-96. http://ejournal.uinsuska.ac.id/index.php/JNSI/article/view/8791

Nurkholis. (2013). Pendidikan dalam Upaya Memajukan Teknologi. Jurnal Kependidikan, 1(1), 2444.

http://ejournal.iainpurwokerto.ac.id/index.php/jurnalkependidikan/article/download/530/473/

Oktariani, O., Febliza, A., \& Fauziah, N. (2020). Keterampilan Berpikir Kritis Calon Guru Kimia sebagai Kesiapan Menghadapi Revolusi Industri 4.0. Journal of Natural Science and Integration, 3(2), 114. https://doi.org/10.24014/jnsi.v3i2.8791

Pitorini, D. E., Suciati, S., \& Ariyanto, J. (2020). Kemampuan Argumentasi Siswa: Perbandingan Model Pembelajaran Inkuiri Terbimbing dan Inkuiri Terbimbing dipadu Dialog Socrates. Jurnal Inovasi Pendidikan IPA, 6(1), 26-38.

Putra, P. D. A., \& Sudarti. (2015). Pengembangan Sistem E-Learning untuk Meningkatkan Keterampilan Berpikir Kritis Mahasiswa Pendidikan Fisika. Jurnal Fisika Indonesia, 19(55), 4548. https://doi.org/10.22146/jfi.24373

Putri, F., Zainuddin, Z., \& Miriam, S. (2019). Meningkatkan Keterampilan Proses Sains Siswa Melalui Model Pembelajaran Inkuiri Terbimbing pada Materi Cahaya. Jurnal Ilmiah Pendidikan Fisika, 3(1), 24. https://doi.org/10.20527/jipf.v3i1.1027

Rambe, Y. A., Silalahi, A., \& Sudrajat, A. (2020). The Effect of Guided Inquiry Learning Model and Critical Thinking Skills on Learning Outcomes. Proceedings of the 5th Annual International Seminar on Transformative Education and Educational Leadership (AISTEEL 2020), 488, 151155. https://doi.org/10.2991/assehr.k.201124.033

Redhana, I. W. (2019). Mengembangkan Keterampilan Abad Ke-21 Dalam Pembelajaran Kimia. Jurnal Inovasi Pendidikan Kimia, 13(1).

Rositawati, D. N. (2019). Kajian Berpikir Kritis Pada Metode Inkuiri. Prosiding SNFA (Seminar Nasional Fisika Dan Aplikasinya), 3, 74. https://doi.org/10.20961/prosidingsnfa.v3i0.28514

Roviati, E., \& Widodo, A. (2019). Kontribusi Argumentasi Ilmiah dalam Pengembangan Keterampilan Berpikir Kritis. Titian Ilmu: Jurnal Ilmiah Multi Sciences, 11(2), 56-66. https://doi.org/10.30599/jti.v11i2.454 
Rusmansyah, Yuanita, L., Ibrahim, M., Isnawati, \& Prahani, B. K. (2019). Innovative Chemistry Learning Model: Improving The Critical Thinking Skill and Self-Efficacy of Pre-service Chemistry Teachers. Journal of Technology and Science Education, 9(1), 59-76. https://doi.org/10.3926/jotse.555

Siswanto, R. D., \& Ratiningsih, R. P. (2020). Korelasi Kemampuan Berpikir Kritis dan Kreatif Matematis dengan Kemampuan Pemecahan Masalah Matematis Materi Bangun Ruang. ANARGYA: Jurnal Ilmiah Pendidikan Matematika, 3(2), 96-103.

Sitindaon, S. F., Bukit, N., \& Turnip, B. M. (2017). The Effect of Guided Inquiry Learning Using PhET Media on Students ' Problem Solving Skill and Critical Thinking. Journal of Education and Practice, 8(21), 129-134.

Sumiyarti, L., Setiadi, D., \& Jamaluddin. (2019). The Development of Learning Devices Based on Guided Inquiry and Affectivities for Students' Critical Thinking Skills. Jurnal Penelitian Pendidikan IPA, 5(2), 194. https://doi.org/10.29303/jppipa.v5i2.275

Suparya, I. K. (2020). Peningkatan Motivasi dan Kemampuan Berpikir Kritis Mahasiswa melalui Model Pembelajaran Berbasis Masalah Berbantuan Media Edmodo. Jurnal Ilmiah Pendidikan Citra Bakti, 07(01), 1-12. https://doi.org/10.38048/jipcb.v7i1.631

Supriyatno, T., Lestari, D. A., \& Utami, U. (2020). The Effectiveness of Guided Inquiry Learning Models for Students' Scientific Performances and Critical Skills. Madrasah: Jurnal Pendidikan Dan Pembelajaran Dasar, 13(1), 1-14. https://doi.org/10.18860/mad.v13i1.9342

Yolanda, Y. (2017). Analysis of Factors Affecting Inflation and Its Impact on Human Development Index and Poverty in Indonesia. European Research Studies Journal, 20(4), 38-56. https://doi.org/10.35808/ersj/873 